\section{Formação Contínua de Professores}

Teve lugar no Porto, nos dias 7, 8 e 9 de Abril 1994 o Forum/94 sobre a Formação de Professores do Ensino Não Superior.

Na sequência do meu desempenho como gestora das Accões de Formação em Quimica que - Departamento de Química da Faculdade de Ciências da Universidade de Lisboa conduziu em 1993, a 0 abrigo do Programa FOCO, senti-me altamente motivada para participar no FORUM 94 tendo-0 encarado como uma Acção de Formação de mim própria. No dia anterior, 6 de Abril, tinha já participado em Aveiro, na sessão sobre Educação em Quimica, no âmbito do Encontro Anual da SPQ. Vi e ouvi de tudo um pouco, argumentos com os quais me identificava e outros que inteiramente rejeitava, ou aos quais pura e simplesmente era alheia. Posições mais radicais, outras mais modernas, traduziram certamente a experiência e o sentir de quantos as evidenciaram e em todas elas haverá algo de válido, embora nenhum possa traduzir a verdade absoluta.

Reforcei a conclusão de que, apesar de tudo, "VALE A PENA SER PROFESSOR". Diz-Se que a função do docente está degradada, mas geração após geração, todos continuamos a lembrar-nos e a orgulhar-nos de termos tido alguns professores que perpetuaremos como exemplos de pedestais de saber cientifico e humano, professores que gostavam do que ensinavam, que nos apresentavam os assuntos com segurança, clare- za e entusiasmo e que nos sabiam tirar dúvidas.

Para ser Professor é preciso saber e saber ensinar. As breves considerações que elaborei dizem respeito ao ensino/aprendizagem de Química, mas também serāo mais ou menos válidas para outras áreas do saber.

A maioria dos professores são licenciados. tendo portanto adquirido na Universidade a sua formação inicial. Concluir que com esta etapa estão formados, é errado. Concluir que, se não estão formados é porque a Universidade não cumpriu, ou nâo sabe cumprir o seu papel, é tanto ou mais errado. Primeiro, para ficar aprovado, basta a um aluno que "saiba" $45 \%$ do que the foi ensinado; depois, ensinar requer um espaço de "maturaçäo" do conhecimento e por fim a Formação é um processo que em si mesmo significa crescimento continuado que em certas alturas implicará fases críticas de reconversão ou requalificação. Estamos, certamente, numa dessas alturas em que docentes dos ensinos Básico e Secundário manifestam alguma insegurança face aos desafios da Nova Reforma do Sistema Educativo e muitos deles voltam-se para a "sua Faculdade", onde, apesar de alguns acharem que a Universidade não tem nada para Ihes oferecer. muitos sentem que não aproveitaram ainda tanto quanto podiam do que a Universidade tinha e continua a ter

Foi, consciente destes apelos, aos quais muitos temos respondido no passado, voluntariamente e de forma mais ou menos esporádica e para não continuarmos a dizer de graça que os alunos do Ensino Secundário chegam à
Universidade a saberem cada vez menos, que sentimos a obrigação moral de quebrar 0 ciclo vicioso e aderimos ao apelo do Programa FOCO. Sentimos que podemos afirmar que, no geral, as centenas de formandos que vieram até nós, sairam melhores profissionais e com vontade de voltar, deixando-nos a sensação de dever cumprido.

Constatamos que a oferta de Acçōes de Formação em Química, a nivel nacional, foi minima quando comparada com outras. Não houve nesta área a "caça aos financiamentos". É que não é fácil! Aliás, não há dinheiro que pague as experiências administrativo-burocráticas negativas porque passámos. 0 s centros de formação têm. no entanto, que dispôr de meios financeiros para cobrir os custos e as Universidades, nos actuais contextos de financiamento, não podem desviar 0 dinheiro que não têm, da formação dos seus alunos regulares e a formação contínua de professores do ensino não superior ainda não constitui um esquema regular nas universidades.

Têm, certamente, relevância, Centros de Formação de Associações de Escolas ou de Professores, mas alunos e professores, depois de membros de uma pequena comunidade, são cada vez mais cidadãos do Mundo e à especificidade de formação que aqueles possam oferecer, tem que se associar a formação Universitária. Mas as Universidades distam das Escolas, e não são muitas, tal como serão poucos os que sabem formar professores de Quimica. Por isso tentaremos encontrar uma forma eficaz de chegar melhor, a mais!

Filomena Camões (FCUL)

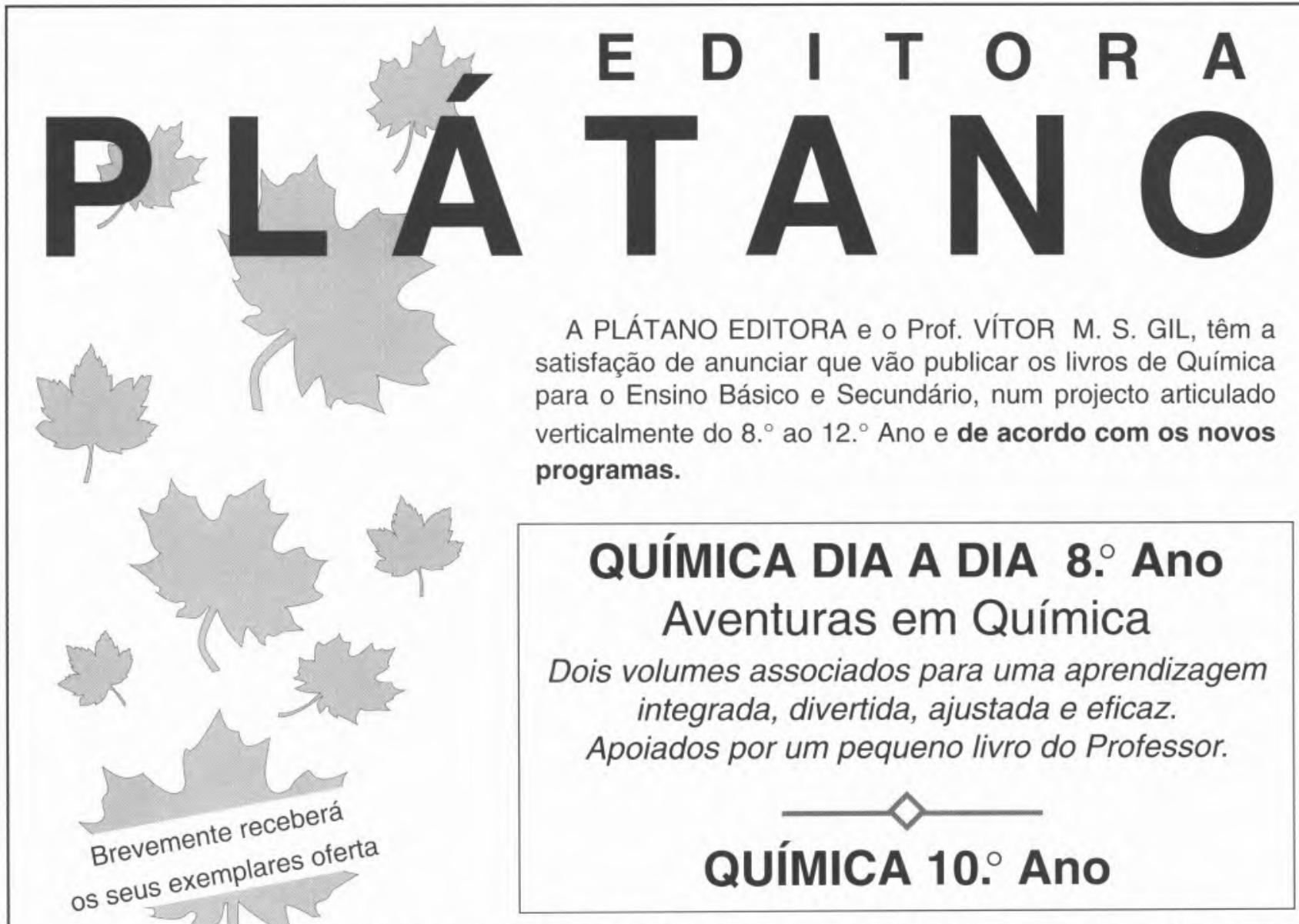

PLÁTANO EDITORA - Av. de Berna, $312^{\circ}$ Esq. 1093 LISBOA CODEX $\mathbf{\sigma}$ (01) 7965107 